\title{
THE FIFA 2022 WORLD CUP AND LABOUR RIGHTS - SEIZING THE MOMENT FOR LABOUR LAW REFORMS IN QATAR
}

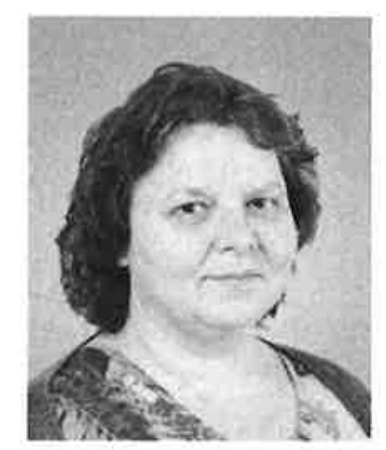

Beryl Ph. ter Haar ${ }^{1}$

Leiden University, Leiden, the Netherlands

b.p.ter.haar@law.leidenuniv.nl

\section{Abstract}

The award of the 2022 World Cup football to Qatar is highly controversial because of the human and labour rights infringements due to the Kafala-system. The argument in this contribution is though that it has also brought something good, namely it created the momentum for change, in particular, to abolish the Kafalasystem. It is difficult to enforce such change through judicial review, as is illustrated by the case FNV c.s. vs FIFA. Soft law procedures, on the other hand, which are based on dialogue, trust and commitment are able to set changes in motions, which is

\footnotetext{
${ }^{1}$ Author

Dr., Assistant Professor, Global and European Labour Law, Leiden University, the Netherlands

Kamerling Onnes Gebouw, Steenschuur 25, room A155, 2311 ES, Leiden, the Netherlands

Kutafin University Law Review Volume 4 Issue 12017
} 
illustrated by the Art. 26 complaint initiated by twelve delegates of the ILO against Qatar and the Specific Instance with the Swiss NCP initiated by BWI against FIFA. This contribution describes the consequences of the Kafala-system, explains why FIFA also fulfils a role in this, even though it concerns the law of the sovereign State Qatar, describes three cases addressing the poor circumstances of the migrant workers in Qatar, and concludes that for these kind of situations soft law proactive processes may be more effective than hard law retrospective judicial review.

\section{Keywords}

FIFA, World Cup 2022, Qatar, Kafala, Forced Labour, ILO Convention No. 29, Labour Inspection, ILO Convention No. 81, OECD NCP, OECD Guidelines, Building and Wood Worker's International, BWI, Corporate Social Responsibility, CSR, Due Diligence

DOI 10.17803/2313-5395-2018.1.9.139-164

\section{TABLE OF CONTENTS}

I. Introduction . . . . . . . . . . . . . . . . . . . . . . . . 140

II. The Kafala System . . . . . . . . . . . . . . . . . 142

III. The (quasi-)legal actions against Qatar and FIFA .......... 146 1. ILO Art. 26 Complaint against Qatar on forced labour and labour inspectorate ....................... 148

2. Two (quasi-)legal actions against FIFA - Due Diligence .... 151

3. Commercial Court of the Canton of Zurich, HG160261-O, 3 January 2017.................. 153

4. Specific Instance regarding FIFA submitted by BWI,

13 October 2015 and 2 May $2017 \ldots \ldots \ldots \ldots \ldots \ldots \ldots \ldots$

IV. Concluding reflections - seizing the moment

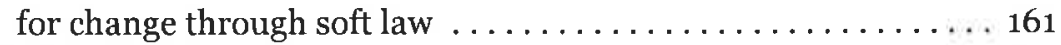

References ............................... 163

\section{INTRODUCTION}

The 2022 World Cup for football will take place in Qatar. Eyes from all over the world will then be on Qatar. However, there are many reasons why our eyes are already turned to Qatar ever since FIFA 
awarded the 2022 World Cup to Qatar. Firstly, the decision of FIFA to grant the 2022 World Cup to Qatar is surrounded by allegations of corruption. ${ }^{2}$ Secondly, like all Arabic states, Qatar uses the so called "Kafala system" to control migrant workers. The Kafala system is much disputed because it leads to modern slavery. ${ }^{3}$ As there are migrant workers who work at the 2022 World Cup construction sites concerns have been raised about their working conditions. This seems right as the 2022 World Cup has been called the most deadly ever. While the sixty fatal accidents connected to the Olympic Games in Sochi was already extreme, compared to two fatal accidents for the 2010 World Cup in South Africa, one for the 2012 Olympics in London and ten for the 2014 World Cup in Brazil, the 1200 reported deaths in Qatar are simply outrageous. ${ }^{4}$ How many worker fatalities have actually taken place at the 2022 World Cup constructions sides is unclear. Firstly it is very difficult to get this information, and secondly, the information that is gained, is distorted since many of the deaths are not investigated, often because they are attributed to natural causes, such as cardiac arrest or respiratory failure, while in fact these "natural causes" are the result of for example dehydration or heat stress. ${ }^{5}$

This contribution focuses on this last issue, the Kafala system, and takes the stand that although FIFA's decision to award the 2022 World Cup to Qatar is highly controversial, from a labour law perspective it may have brought something positive. In May 2017 FIFA adopted a Human Rights Policy based on the United Nations Global Compact principles and the Ruggie Framework, which covers activities in countries hosting

${ }^{2}$ Laughland O. FIFA official took bribes to back Qatar's 2022 World Cup bid, court hears. The Guardian. 15 November 2017.

3 E.g.: www.migrant-rights.org/2015/03/understanding-kafala-an-archaic-lawat-cross-purposes-with-modern-development/ (accessed 22 December 2017).

4 Cf.: www.statista.com/chart/3504/fifas-corruption-also-has-a-human-cost/ (accessed 22 December 2017).

$`$ Cf.: Conn D. Thousands of Qatar World Cup workers "subjected to lifethreatening heath". The Guardian. 27 September 2017. See also: www.bbc.com/ news/magazine-33019838; Liew J. World Cup 2022: Qatar's workers are not workers, they are slaves, and they are building mausoleums, not stadiums. The Independent. 3 October 2017; ITUC. The case against Qatar. Host of the FIFA 2022 World Cup. Special Report. March 2014. 
World Cups. ${ }^{6}$ In October 2017 Qatar announced reforms to dismantle the Kafala system. ${ }^{7}$ Both initiatives have been hailed as positive changes.

The aim of this contribution is to analyse how various (quasi-) legal initiatives and pressures have contributed to these changes. I will first describe the Kafala system and its susceptability for forced labour in more detail. Secondly, I will describe various (quasi-) legal initiatives and forms of pressure put on Qatar to abolish the Kafala system. I will also describe the pressure directed to FIFA to take its social responsibility seriously and exert all of its influence over its partners in Qatar, and over partners organising a World Cup more generally. Thirdly, I will describe the two main changes these (quasi-) legal initiatives have contributed to, i.e. the announced reforms of the Kafala system in Qatar and FIFA's Human Rights Policy. I will conclude with a reflection on the process towards these changes generated by these (quasi-) legal initiatives and forms of pressure put on Qatar and FIFA.

\section{THE KAFALA SYSTEM}

This section describes the Kafala system as a legal framework to control migrant workers. To illustrate the consequences of this system it also includes some examples from the practice based on stories that have been published in various newspapers and reports.

Kafala, which means sponsorship in Arabic, is a system of control. In the context of migrant workers in Arabic countries, among which Qatar, it is a system in which governments have delegated oversight and responsibility for migrant workers to private citizens and companies. ${ }^{8}$ Sponsors are given a set of legal powers to control migrant workers. Often the sponsor is the employer of the migrant worker. This gives the employer not only the control over how the worker has to

${ }^{6}$ See: www.fifa.com/governance/news $/ y=2017 / \mathrm{m}=6 / \mathrm{news}=$ fifa-publishes-land mark-human-rights-policy-2893311.html, which includes a link to the policy document (accessed 23 December 2017).

7 Available at: www.ituc-csi.org/breakthrough-to-end-kafala-after (accessed 23 December 2017).

${ }^{B}$ See for an elaborate explanation of the Kafala system at the website of migrantrights.org.

Kutafin University Law Review Volume 5 Issue 12018 
Beryl Ph. ter Haar

THE FIFA 2022 WORLD CUP AND LABOUR RIGHTS -

perform his duties (which is one of the core elements of the employment relationship - subordination), but also about the choice of employment and even residence. Thus, without the permission of the sponsor (ie employer), a worker cannot change his job, quit his job, or leave the country. Moreover, the sponsor has the power to cancel the residency visa of a worker who has quit his job without permission. Such an action turns the worker automatically into an illegal resident in the country, often giving cause to deportation proceedings that include spending time in prison. ${ }^{9}$

In practice this commonly leads to the following situations. ${ }^{10}$ Workers are recruited by special agencies that ask high fees, varying between USD 1 ooo to USD 3500 . However, given the better jobs and higher salaries, migrant workers are willing to pay such fees with the idea that they will easily earn this back. However, it is not uncommon that upon arrival the migrant worker is told that the contract he signed via the recruitment agency is no longer valid and is offered another contract with a lower wage and another job position. Since they have to pay back the recruitment fees (and some other costs, for instance for an orientation seminar, medical examination, and insurance) they have no other option than accepting this new, less favourable, contract. Also common practice is the confiscation of the passport by the sponsor, which, besides the formal requirements such as an exit visa, makes it more difficult to leave employment or the country.

After having accepted the changed contract, the migrant worker soon finds out that the employment is very different from what was agreed. It can be a completely different position, for example, instead of working at administration in an office the migrant worker finds himself building a football stadium or a constructing a road. It can also be that additional work is required, for instance, in the morning it is cleaning activities at a

9 Available at: www.migrant-rights.org/2015/03/understanding-kafala-anarchaic-law-at-cross-purposes-with-modern-development/.

${ }^{10}$ This is mainly based on testimonials of migrant workers included in: ITUC. The case against Qatar. Host of the FIFA 2022 World Cup. Special Report. March 2014; and the introduction in: Liew J. World Cup 2022: Qatar's workers are not workers, they are slaves, and they are building mausoleums, not stadiums. The Independent. 3 October 2017. 
school and in the afternoon and evening it entails hospitality services in a hotel. Besides these unpleasant changes, the working conditions and circumstances are often also terrible. Examples have been registered of extremely long working hours, such as starting to work from 6 am till $12 \mathrm{pm}$ in one job and then continue working from $3 \mathrm{pm}$ till midnight in the other job, leading to sleep deprivation. Although a six day working week is respected, it is not uncommon that workers are compelled to work a few hours on their day off. Overtime is also a regular feature of working in Qatar. Migrant workers have indicated that they were working double shifts of 12-14 hours per day with only 2-3 hours of overtime being paid. Annual leave days can easily be denied with the excuse that there is no one to replace the worker. Since the sponsor (which most of the time is also the employer) holds the passport, the worker cannot just take up his annual leave days. Working outdoors in Qatar during summertime is extremely harsh because of the heat; it can easily reach 50 degrees Celsius. ${ }^{11}$ An annually issued ministerial decree stipulates that from 15 June to 31 August outdoor workers should work no more than five hours in the morning till $11.30 \mathrm{am}$ at the latest and start the evening shift no earlier than $3 \mathrm{pm}$. However, since the decree is legally not binding, many companies do not comply with it. Also, it has been commented that instead of fixed dates, the rule should apply "whenever the temperatures goes up beyond normal levels." ${ }^{12}$ Salary payments are regularly delayed, there is a lack of safety procedures and materials, and workers are inexperienced and non-trained for the jobs required to do. The Kafala system makes it impossible for workers to bring any changes in their situation. Any form of complaint, comment, or resistance is met with retaliation by their sponsor (i.e. the employer). Workers that go on strike have been arrested, imprisoned and placed at risk of deportation. ${ }^{13}$

${ }^{11}$ It is also for this reason that the 2022 World Cup will take place in winter and not in summer.

${ }_{12}$ Cf.: Toumi H. Calls to implement summer working hours in Qatar. Gulf News. 15 May 2011.

${ }^{13}$ ITUC. Qatar Arrests 100 Striking Workers for Deportation. 26 November 2014.

Kutafin University Law Review Volume 5 Issue 12018 
Additionally, many migrant workers have to share accommodation with 8-10 people, sleeping in bunkbeds, while kitchens and washrooms need to be shared with many more persons. These are poor circumstances. Sharing a small room with so many persons hardly provides the environment for a good night's rest. Taking good care of personal hygiene and preparing nutritious meals are also challenging under such circumstances.

The above leads the International Trade Union Conferderation (ITUC) to conclude that:

"[m]igrant workers have reported finding themselves in exploitative situations, such as being paid far lower than promised wages, experiencing numerous unspecified deductions from wages, not being paid at all for months and living in abysmal living conditions with dozens of co-workers crammed into small unventilated shelters without proper plumbing, water and electricity."14

These findings are not limited to the workers involved with the construction works for the 2022 World Cup. Nonetheless, these problems affect these migrant workers especially, because since the award of the 2022 World Cup the number of migrant workers increased considerably, some sources report up to half a million workers, ${ }^{15}$ while others claim that the number of migrant workers has doubled. ${ }^{16}$ Having to provide decent working and living conditions for so many additional workers in such a short period of time is challenging for any legal and administrative system. For a country like Qatar which hosts most of the migrant workers of the world; based on the Qatari - migrant workers represent $94 \%$ of the work force and these workers represent $70 \%$ of the total population. ${ }^{17}$ In this context it has been argued that abolishing the Kafala system will disrupt the Qatari society too much. Qatari

${ }^{14}$ ITUC. The case against Qatar. Host of the FIFA 2022 World Cup. Special Report. March 2014. P. 28.

15 Ibid. P. 17.

${ }^{16}$ Grell T. FIFA's Responsibility for Human Rights Abuses in Qatar. Part I: The Claims against FIFA. Asser International Sports Law Blog. 28 February 2017.

${ }_{17}$ Available at: www.theguardian.com/news/datablog/2013/sep/26/qatarmigrants-how-changed-the-country; and The Middle East's migrant workers. Forget about rights. The Economist. 10 August 2013. 
people fear that under a less strict regime migrant workers will unite, coalesce and perhaps even mobilise against them. ${ }^{18}$ The Kafala system deliberately puts migrant workers under a strict control. ${ }^{19}$ However, with the number of fatal accidents in the run up to major sports events being the highest ever, ${ }^{20}$ many voices are raised calling the need to abolish the Kafala system. Additionally, these worker fatalities have also raised questions about the role of FIFA, especially in the context of corporate social responsibility.

\section{THE (QUASI-)LEGAL ACTIONS AGAINST QATAR AND FIFA}

As indicated in the introduction the award of the 2022 World Cup to Qatar has been contested for several reasons. The extremely high number of worker fatalities in the run up to the event as consequence of the Kafala system proves that from a human and labour rights perspective FIFA's decision is highly questionable: is a sports event worth the death of so many workers? The simple answer is no. However, still I claim that despite all this it has also brought something positive. Before the award of the 2022 World Cup the Kafala system was already

18 Ibid.

${ }_{19}$ A much discussed case in the global football community is the case of the French football player Zahir Belounis, whose contract as captain of the Qatari team El Jaish was abruptly terminated leaving him without pay. When he brought legal actions against his former team, El Jaish (his employer and sponsor) denied his exit visa. Consequently, Belounis could not leave the country and kept him trapped in Qatar for two more years without income. See more elaborately on this: Erfani A. Kicking Away Responsibility: FIFA's Role in Response to Migrant Worker Abuses in Qatar's 2022 World Cup. Jeffrey S. Moorad Sports Law Journal. 2015. 22 (2). 623. Available at: http://digitalcommons.law.villanova.edu/mslj/vol22/iss2/.

${ }^{20}$ For completeness sake it should be noticed that compared to other sports events, the construction works in Qatar may rank among the most extensive, since it is not limited to building football stadiums, but also includes building a new city called Lusail which will include a shopping mall, zoo, schools, a hospital and housing for over 250000 residents (cf.: www.huffingtonpost.com/2014/08/25/qatars-newworld-cup-city_n_5698138.html), as well as an airport and the necessary roads to create a connecting infrastructure between the cities and sports stadiums. 
shown to result in human trafficking and modern forms of slavery, ${ }^{21}$ however, apparently not enough pressure could be created to push Arabic countries to abolish it since little has changed. ${ }^{22}$ The 2022 World Cup seems to have created a momentum to exert the necessary pressure for changes in Qatar. ${ }^{23}$

The same argument can be made with respect to the social responsibility of FIFA as the commissioning organisation of the World Cup event. In these times of globalisation in which multinational companies are under pressure to undertake due diligent Corporate Social Responsibility (CSR) for what is going on in the production and value chains, it is not surprising that such pressure is also put on transnational operating organisations like FIFA and the International Olympic Committee (IOC). For FIFA the award of the 2022 World Cup has created the momentum in which it can no longer deny its CSR for what happens in the event's host country in the run up to the event.

This section describes three (quasi-)legal actions, of which one against Qatar: an Article 26 complaint with the International Labour Organisation (ILO) and two against FIFA: a case initiated jointly by the Dutch trade union FNV, the Bangladeshi Free Trade Union Congress, the

${ }^{21}$ E.g.: The first document about the Kafala system within the International Labour Organisation dates back to 2002. This is a working paper on migrant women in the United Arab Emirates. In this report the vulnerability of migrant workers under the Kafala is extensively described. When entering the word "Kafala" on the ILO's website, it results in 236 hits. At the website of Human Rights Watch information and reports date back to 2007. The title of the news release on 17 December 2007, "Asian Migrant Workers Abandoned to Abuse", gives a clear indication about the vulnerability of these workers under the Kafala system.

${ }_{22}$ Only Bahrain abolished the Kafala system: Harmassi M. Bahrain to end "slavery" system. BBC Arabic Service Radio. 6 May 2009. Available at: news.bbc. co.uk/2/hi/middle_east/8035972.stm (accessed 23 December 2017). To what extent Bahrain really abolished the Kafala system is disputable. Cf.:, Bahrain Moves to Reform Kafala, Exclusions Remain. Americans for Democracy. 28 October 2016. Available at: www.adhrb.org/2016/10/bahrainkafala/ (accessed 23 December 2017).

${ }_{23}$ The number of reports by international and non-governmental organisations increases significantly after 2010. Also the number of organisations taking up on the subject increases. The hearing at the European Parliament on sports and Human Rights in Qatar is one example (discussed in section 3.2) and so is the 2014 report of United Nation's Human Rights Council's special rapporteur François Crépeau on the human rights of migrants in Qatar. Available at: http://www.ohchr.org/Documents/ Issues/SRMigrants/A-HRC-26-35-Add1_en.pdf (accessed 24 December 2017). 
Bangladesh Building and Wood Workers Federation and the Bangladeshi citizen Nadim Shariful Alam against Qatar filed with the Commercial Court of the Canton of Zurich, Switzerland; and a specific instance filed with the OECD national contact point of Switzerland by global trade union federation Builders and Wood Worker's International.

\section{ILO Art. 26 Complaint against Qatar on forced labour and labour inspectorate}

On 12 June 2014 the Director-General of the International Labour Conference received a communication to launch an Article 26 complaint alleging non-observance by Qatar of the Forced Labour Convention (No. 29) and the Labour Inspection Convention (No. 81) submitted by delegates from Belgium, Libya, Jordan, the United Kingdom, Denmark, France, Canada, Pakistan, Kenya, and Tunisia. ${ }^{24}$ The complaint argues that the problem of forced labour affects the migrant worker population of roughly 1.5 million and that the Qatari Government fails to maintain a legal framework sufficient to protect the rights of migrant workers consistent with international law. It raises particular concern since the Qatari Kafala system, which is among the most restrictive of the region, facilitates exacting forced labour making it very difficult for a migrant worker to leave an abusive employer. ${ }^{25}$

In its reply date 26 January 2015, the Qatari Government provided information on measures taken to combat all forms of forced labour and human trafficking. First of all the Government stressed that forced labour is penalised by criminal law. Furthermore, the Government stated that the draft law to replace the Kafala system has been explicitly announced and that the new law is based on a contract system. The draft law also amends the provisions relating to the so called "release permit", which will make a government body responsible for the worker instead

${ }^{24}$ Governing Body, Complaint alleging non-observance by Qatar of the Forced Labour Convention, 1930 (No. 29), and the Labour Inspection Convention, 1947 (No. 81), made by delegates to the $103^{\text {rd }}$ Session (2014) of the International Labour Conference under article 26 of the ILO Constitution, $323^{\text {rd }}$ Session, Geneva 12-27 March 2015, GB.323/INS/8(Rev.1).

25 Ibid. P. 1. 
of the employer. ${ }^{26}$ Other changes involve recruitment fees, contract frauds, the confiscation of passports (which is already penalised by law), and conditions and specifications for housing. ${ }^{27}$ Regarding the efforts used to develop the labour inspection system, the Government emphasises that it pays great attention to the mission of labour inspection to ensure the enforcement of laws which provide protection to workers employed in Qatar. Thus, the number of inspectors has steadily increased up to 294, the efficiency of the inspections has improved, and a new department on occupational safety and health at the Ministry of Labour and Social Affairs has been established.$^{28}$ Furthermore, the Government extensively describes existing practices and legal powers of the labour inspectorate. ${ }^{29}$ Changes are also described and announced with respect to the grievance mechanisms for workers. These include the establishment of a team specialised in providing guidance and counselling to workers, which also makes field visits to receive complaints. Other measures include ensured translation, distribution of newsletters, the launch of a hotline, accounts on social media, the establishment of an office at the Ministry to collaborate with workers who have initiated legal procedures against employers (including providing legal aid), and actions to raise awareness with migrant workers about their rights. ${ }^{30}$ With respect to the issue of the protection of wages, the Government indicates that a draft amendment of a few sections of the Labour Code has been drawn up so as to impose dissuasive penalties on employers who are in violation of this Code. ${ }^{31}$

From 7-11 February 2015 a high-level mission was undertaken by ILO officers, under supervision of the Director of the International Labour Standards Department. ${ }^{22}$ During the mission the ILO officers met with various government officials and the Supreme Committee for

\footnotetext{
${ }^{26}$ Ibid. P. 8.

27 Ibid. P. 8-9.

28 Ibid. P. 9-10.

29 Ibid. P. 10-11.

3о Ibid. P. 12-14.

${ }^{31}$ Ibid. P. 15.

${ }^{32}$ Ibid. P. 16.
} 
Delivery and Legacy (SC). ${ }^{33}$ They also visited, among other locations, the Labour Inspectorate, the construction site for Al Wakrah Stadium, and a set of workers' accommodations near Doha. ${ }^{34}$ The overall conclusion of the mission was that despite the recent measures taken by the Qatari Government to improve the working conditions of the migrant workers, many challenges remain. Further progress could be made, especially concerning the timely payment of wages, the ability to change employers and access to effective complaints mechanisms, since these leave workers in a precarious situation. ${ }^{35}$

Despite all the changes announced by the Qatari Government, the Governing Body expressed its concerns about the gravity of the issues raised in the complaint to the Officers of the Governing Body recommending a) that a high-level tripartite mission be undertaken to Qatar before June 2015 and b) to postpone a decision on setting up a commission of inquiry to its $325^{\text {th }}$ session (November 2015)..$^{36}$ The decision was again postponed at the $325^{\text {th }}$ session and the $328^{\text {th }}$ session (November 2016). ${ }^{37}$ On 31 October 2017, at its $33^{\text {st }}$ session, the Governing Body decided to close the complaint procedure. Instead of monitoring via the complaint procedure, the cooperation between the ILO and Qatar is continued in the period 2018-2020, via a Technical Cooperation Project and its implementation modalities..$^{38}$ It is stated that the Technical Cooperation Project reflects the common commitment of the ILO and Qatar to cooperate on ensuring compliance with ratified international labour Conventions. This will be done through: improvement in payment of wages; enhanced labour inspection and OSH systems; refinement of the contractual system that replaced the

33 This is the organisation between FIFA and the government of the organising country, i.c. the Qatari Government.

${ }_{34}$ GB.323/INS/8(Rev.1). P. 17-27.

35 Ibid. P. 29.

${ }_{36}$ Ibid. P. 2.

${ }^{37}$ Governing Body, Complaint alleging non-observance by Qatar of the Forced Labour Convention, 1930 (No. 29), and the Labour Inspection Convention, 1947 (No. 81), made by delegates to the 103rd Session (2014) of the International Labour Conference under article 26 of the ILO Constitution, $331^{\text {st }}$ Session, Geneva 26 October 9 November 2017, GB.331/INS/13(Rev.). P. 1.

${ }^{38}$ Ibid. P. 3. 
kafala system and to improve labour recruitment procedures; increased prevention, protection and prosecution against forced labour; and promotion of the workers' voice. ${ }^{39}$

\section{Two (quasi-)legal actions against FIFA - Due Diligence}

Before addressing the two (quasi-)legal actions against FIFA a few words need to be addressed about why to bring a claim against FIFA if the problem lies with Qatar's Kafala system. Against the background of corporate social responsibility (CSR) it is generally accepted that multinational enterprises influence what happens with the human and labour rights in their value and production chains. To what extent a multinational enterprise will be held responsible depends on how strong its influence is. The latter depends on the relationship between the hub company and its subsidiaries and subcontractors. The stronger this relationship is the bigger the influence is presumed to be and the weaker this relationship is, the smaller the influence is presumed to be. There are different reasons why the relationship between the hub company and its subsidiary or subcontractor is either strong or weak. In general two main causes can be indicated: the hierarchical structure between the two entities; and the position in the production or value chain. The former refers to the initial power relationship between the two entities. If the hierarchical structure is strong (meaning that the hub company basically decides everything for the whole chain), the influence is presumed to be strong. If the hierarchical structure is weak, for example because the companies are related in the structure of a network or the subcontractor is a so called "turnkey" company meaning that it also works for other hub companies in the same sector, the influence of the hub company will be weak. ${ }^{40}$

${ }^{39}$ Ibid. P. 31.

$4^{40}$ Cf.: Gereffi G., Humphrey J., and Sturgeon T., The governance of global value chains. Review of International Political Economy. 2005. 12:1. Pp. 78-104; and applied more specifically to the situation of labour law: ter Haar B. P. and Keune M. One step forward or more window-dressing? A legal analysis of the recent CSR initiatives in the garment industry in Bangladesh. The International Journal of Comparative Labour Law \& Industrial Relations. 2014. 30:1. Pp. 5-26. 
The position of the subsidiary or subcontractor refers to how close the contractual relationship is with the hub company, both in terms of percentage of supplying as well as in terms of the number of contracts between them. Thus, a subsidiary or subcontractor that is mainly producing for the hub company is considered to be more under the influence of the latter, than a company that also produces for other hub companies (this also relates the hierarchical structure described above). In production chains it is common practice that a subsidiary or subcontractor contracts part of its activities out to another subsidiary or subcontractor. For instance, because it has overbooked itself and in order to make the deadlines it needs assistance by another company, or it receives a last minute order with a very short deadline. Last minute changes in an existing order may also result in pressure on the delivery times forcing the company to contract out (part of) the production. It can also be that the product simply exists of many different components which are assembled in different stages by different companies that deliver (parts of) the full product. Consequently, the line of outsourcing from one company to another can be very long, which weakens the relationship with the hub company every time a new contract is added to the chain.

Within the literature of CSR this principle of what could be called "level of influence" is part of due diligence, which refers to the manner in which the multinational enterprise respects and conducts its CSR policy. For example, paragraph ten of the general principles of the OECD guidelines for Multinational Enterprises (MNEs) stipulates that MNEs are expected to:

"Carry out risk-based due diligence, for example by incorporating it into their enterprise risk management systems, to identify, prevent and mitigate actual and potential adverse impacts as described in paragraphs 11 and 12, and account for how these impacts are addressed. The nature and extent of due diligence depend on the circumstances of a particular situation."41

Paragraph 11 refers to avoiding adverse impacts on human and labour rights through the MNEs own activities and paragraph 12

${ }^{41}$ OECD Guidelines for Multinational Enterprises, 2011 edition. Available at: http://mneguidelines.oecd.org/guidelines/. 
refers to prevent or mitigate an adverse impact where the MNE itself has not contributed to the adverse impact, but when the impact is nevertheless directly linked to the operations, products or services by a business relationship. Paragraph 14 of the Commentary on the General Principles further specifies that "contributing to" an adverse impact is to be interpreted as "a substantial contribution, meaning an activity that causes, facilitates or incentivises another entity to cause an adverse impact and does not include minor or trivial contributions." Furthermore, it is specified in paragraph 14 that the term "business relationship' includes relationships with business partners, entities in the supply chain and any other non-State or State entities directly linked to its business operations, products or services."

Although FIFA disputed whether the OECD Guidelines for MNEs are applicable to an organisation like FIFA (see the specific instance with the Swiss NCP as discussed below), pursuant to Article 37 of the FIFA 2016 Statutes it is clear that FIFA has an impact on the activities of the countries hosting the World Cup, since it stipulates that "the Organising Committee for the FIFA World Cup shall organise the FIFA World Cup in compliance with the provisions of the regulations applicable to this competition, the List of Requirements and the Organising Association Agreement." ${ }^{22}$ In principle FIFA doesn't seem to deny this in either of the two cases discussed here. The main question addressed in both cases though is to what extent is FIFA expected to limit its (potentially) adverse impacts?

\section{Commercial Court of the Canton of Zurich, HG160261-0, 3 January 2017}

The first (quasi-)legal action to be discussed in this section is the case filed with the Commercial Court of the Canton of Zurich, Switzerland (further referred to as "Court"). The case was initiated jointly by the Dutch trade union FNV, the Bangladeshi Free Trade Union Congress, the Bangladesh Building and Wood Workers Federation and the Bangladeshi citizen Nadim Shariful Alam (together further referred

${ }^{42}$ Grell T. FIFA's Responsibility for Human Rights Abuses in Qatar. Part I: The Claims against FIFA. Asser International Sports Law Blog. 28 February 2017. 
to as "Plaintiffs"). The Plaintiffs submitted three claims.43 Firstly, they requested the Court to order FIFA to redress the ongoing human rights violations by pressing the responsible Qatari authorities to abolish the controversial Kafala system and to ensure that human rights and fundamental freedoms of migrant workers are preserved. Secondly, and alternatively, they asked the Court merely to declare the unlawfulness of those human rights violations. Thirdly, the Bangladeshi worker Nadim Shariful Alam sought damages of USD 4 ooo and a satisfaction amounting to $\mathrm{CHF} 30$ o00.44

More particularly, the Plaintiffs contend that the kafala system violates Qatari domestic law, Swiss law and international labour and human rights law..$^{45}$ In particular, as Grell describes, the Plaintiffs "argue that Qatar facilitates forced labour by: (i) the employer's control over residency permits; (ii) prohibiting workers to switch employer; (iii) allowing abusive contracts; (iv) allowing high recruitment fees; (v) not effectively opposing passport confiscation; and (vi) the lack of effective redress and legal enforcement of the protection of workers' rights. Given that their passports are routinely being retained, migrant workers are also constrained in their freedom of movement. Owing to the fact that Qatari domestic law prohibits migrant workers from organising in trade unions, their freedom of association is virtually non-existent. Furthermore, the Plaintiffs invoke the violation of the fundamental right not to be discriminated against and the right to an effective remedy." 46

${ }^{43}$ Since the court's ruling is not publicly accessible this part is based on the descriptions provided by Thomás Grell in his blogs on this case: FIFA's Responsibility for Human Rights Abuses in Qatar. Part I: The Claims against FIFA. Asser International Sports Law Blog. 28 February 2017; and FIFA's Responsibility for Human Rights Abuses in Qatar. Part II: The Zurich Court's Ruling. Asser International Sports Law Blog. 6 March 2017.

${ }^{44}$ Grell T. FIFA's Responsibility for Human Rights Abuses in Qatar. Part II: The Zurich Court's Ruling. Asser International Sports Law Blog. 6 March 2017.

45 Lawsuit submitted to the Court by the Plaintiffs on 8 December 2016, para. 259.

${ }^{46}$ Grell T. FIFA's Responsibility for Human Rights Abuses in Qatar. Part I: The Claims against FIFA. Asser International Sports Law Blog. 28 February 2017. 
To address the link between FIFA and Qatar's alleged failure to comply with human and labour rights obligations, the Plaintiffs refer to three sets of rules: FIFA's own rules; Swiss tort law; and international law, in particular the UN Guiding Principles on Business and Human Rights. Pursuant to Article 3 of the FIFA 2016 Statutes FIFA commits itself to respect all internationally recognised human rights and to promote the protection of these rights. ${ }^{47}$ In Article 4 FIFA 2016 Statutes FIFA states that any kind of discrimination is strictly prohibited and punishable by suspension or expulsion. Via Article 37 FIFA 2016 Statutes, FIFA forces the World Cup host to sign an Organising Association Agreement which holds a list of requirements concerning, among others, infrastructure, security, broadcasting rights, and financing. Remarkable it lacks any demands on human and labour rights. ${ }^{48}$ Plaintiffs interpret this stringent agreement as a "take-itor-leave-it" deal, claiming that FIFA exerts tremendous influence on the host States to modify their national legislation, at least for the duration of the World Cup. ${ }^{49}$ Furthermore, Plaintiffs refer to the power of FIFA to exclude countries from the bidding procedure (as was done with Indonesia) or suspend countries' membership (as was done with Guatemala in October 2016 and Nigeria in 2014). That such actions can also be done for reasons of human and labour rights, as was the case with South Africa during the apartheid regime. ${ }^{\circ 0}$ With these arguments Plaintiffs aim to demonstrate the considerable influence FIFA has over the World Cup host country when it wants.

47 Available at: resources.fifa.com/mm/document/affederation/generic/02/78/ 29/o7/fifastatutsweben_neutral.pdf (accessed 24 December 2017).

${ }^{48}$ Cf.: Grell T. FIFA's Responsibility for Human Rights Abuses in Qatar. Part I: The Claims against FIFA. Asser International Sports Law Blog. 28 February 2017, with reference to the Organising Association Agreement with South Africa. Available at: ccs.ukzn.ac.za/files/Fifa\%20agreement\%20with\%20SA\%202.pdf (accessed 24 December 2017).

49 Plaintiffs refer in this context to the so called "Budweiser law" enacted by Brazil to allow beer sales during the 2014 World Cup while the sale of alcohol was prohibited in Brazilian stadiums for over ten years. Cf. Grell T. FIFA's Responsibility for Human Rights Abuses in Qatar. Part I: The Claims against FIFA. Asser International Sports Law Blog. 28 February 2017.

50 Grell T. FIFA's Responsibility for Human Rights Abuses in Qatar. Part I: The Claims against FIFA. Asser International Sports Law Blog. 28 February 2017. 
Swiss tort law applies by virtue of the choice of law rules laid down in the Swiss Act on Private International Law. The core argument of Plaintiffs is based on the principle of "endangerment". As explained by Grell this means that a person who brings about a dangerous situation shall take the necessary precautions in order to prevent potential harm. ${ }^{51}$ Plaintiffs argue that FIFA's obligation under this law is triggered because it failed to demand from Qatar to set aside the Kafala system. ${ }^{52}$

Since FIFA communicated its commitment to abide by the UN Guiding Principles, the Plaintiffs argue that they make a reasonable point of reference to understand FIFA's responsibility for human and labour rights. Additionally, FIFA asked John Ruggie ${ }^{53}$ to develop recommendations on what it means for FIFA to embed and respect human and labour rights across its global operations. ${ }^{54}$ The situation of Qatar's migrant workers is among the reasons to initiate these moves. ${ }^{55}$

Since the Court concluded that the case could be decided immediately, FIFA was not invited to express its views. ${ }^{56}$ The Court found the claims of the Plaintiffs inadmissible, since they are too ambiguous to be enforceable. The first Claim was too vague because it did not specify the Qatari authorities to which FIFA should turn in order to ameliorate the humanitarian conditions for World Cup-related migrant workers. ${ }^{57}$ In its in obiter dicta comments, the Court further explained that the first claim is more likely to fall within the ambit of public law (instead of commercial law), and that a decision requiring a private association (i.e. FIFA) to interfere in domestic affairs of a

\footnotetext{
51 Ibid.

$5^{2}$ Ibid.

53 John Ruggie is professor at Harvard University and designed the UN Guiding Principles and the supporting framework "Protect, Respect and Remedy".

${ }_{54}$ Available at: www.solidar.ch/sites/default/files/ruggie_humanrightsfifa_ reportapril2016.pdf (accessed 24 December 2017).

$5 \overline{5}$ Ibid. P. 4.

${ }^{56}$ Such is possible on the grounds of the Swiss Code of Civil Procedure. See on this: Grell T. FIFA's Responsibility for Human Rights Abuses in Qatar. Part II: The Zurich Court's Ruling. Asser International Sports Law Blog. 6 March 2017.

${ }^{57}$ Ruling of the Commercial Court of the Canton of Zurich, HG160261-O, 3 January 2017. P. 7.
} 
sovereign State (i.e. Qatar) could be potentially deemed unlawful..$^{8}$ The second Claim was also too vague because it did not specify which conduct of FIFA should be declared unlawful. Consequently, it would be impossible for FIFA to defend itself. ${ }^{99}$ The third Claim was rejected due to the absence of a commercial dispute between Mr. Alem and FIFA. ${ }^{60}$

As a result of the inadmissibility of the first two Claims and the rejection of the third Claim, the Court did not get to the merits of the question to what extent FIFA should take its responsibility for human and labour rights infringements by the host organising its World Cup. It did not even consider whether such an obligation rests upon FIFA. This is different in the next case, i.e. the specific instance at the Swiss NCP initiated by global trade union federation BWI.

\section{Specific Instance regarding FIFA submitted by BWI, 13 October 2015 and 2 May 2017}

On 28 May 2015 the Building and Wood Worker's International (BWI) raised a specific instance with the Swiss NCP concerning human and labour rights violations of migrant workers related to the construction of facilities for the FIFA 2022 World Cup in Qatar. ${ }^{61}$ BWI claims that FIFA violated the OECD Guidelines for MNEs by appointing Qatar as the host State for the 2022 world Cup. Furthermore, BWI claims that at the time FIFA awarded the 2022 World Cup to Qatar the human and labour rights violations were well documented and know, yet FIFA's Bidding Agreement did not include any requirements to address human and labour rights. Therefore, BWI argues, FIFA failed to conduct adequate and ongoing human rights due diligence as called for in the 2011 OECD Guidelines for MNEs. More specifically, BWI argues that FIFA was at least expected to take adequate steps "to cease or prevent its own contribution to the human rights violations of migrant workers

${ }^{58}$ Grell T. FIFA's Responsibility for Human Rights Abuses in Qatar. Part II: The Zurich Court's Ruling. Asser International Sports Law Blog. 6 March 2017.

59 Ruling of the Commercial Court of the Canton of Zurich, HG160261-O, 3 January 2017. P. 8.

${ }^{60}$ Grell T. FIFA's Responsibility for Human Rights Abuses in Qatar. Part II: The Zurich Court's Ruling. Asser International Sports Law Blog. 6 March 2017.

${ }^{61}$ NCP Switzerland, Initial Assessment. 13 October 2015. P. 1. 
and to use its leverage with the Government of Qatar to accelerate the necessary labour and other reforms that would help prevent and mitigate remaining human rights violations." ${ }^{2}$ BWI asked the Swiss NCP to offer its good offices, firstly, to identify steps to be taken by FIFA, secondly to address the responsibility of FIFA to use its alleged leverage with the Government of Qatar in order to accelerate labour and other human rights-related reforms. BWI submitted a list of topics, which can be summarised as the development and implementation of a human and labour rights due diligence policy based on the OECD Guidelines for MNEs and the UN Guiding Principles on Business and Human Rights, including inspections, grievance mechanisms, stakeholder involvement (including trade unions), and the use of its leverage to engage with the Qatari Government to accelerate human and labour rights related reforms. ${ }^{63}$

FIFA submitted a written statement to the Swiss NCP on 27 July 2015 in which it emphasised its commitment to good governance principles. However, FIFA also believes it is important to discuss how the OECD Guidelines for MNEs apply to FIFA, since it is an association registered in the Commercial Register in accordance with Article 6off of the Swiss Civil Code. ${ }^{64}$ Furthermore FIFA stated that it is imperative that all workers in Qatar enjoy fair and safe working conditions and to advance that end FIFA encourages and facilitates dialogue between stakeholders in Qatar and international organisations. Additionally FIFA provided an overview of activities it already undertook regarding Qatar at the highest political level, as well as of the standards and codes of conduct FIFA adheres to. Nonetheless, FIFA also considers that the protection of workers' rights is as an urgent and complex matter which requires "the coherent involvement and support of all relevant stakeholders such as, among others, enterprises having construction sites in Qatar and the migrant workers' countries of origin." 65 Therefore, FIFA believes that the most efficient and effective approach is a continuous multi-

\footnotetext{
62 Ibid.

${ }^{63}$ Ibid. P. 2.

64 Ibid. P. 3.

65 Ibid.
} 
stakeholder approach and confirms its commitment to dialogue and close monitoring of the progress.

In its Initial Assessment the Swiss NCP considered the applicability of the OECD Guidelines to the responding party. Thereto, the NCP first reiterated the definition of the term "multinational enterprise" as interpreted by the OECD Guidelines. The term is interpreted very wide and includes enterprises in all sectors of the economy of which the ownership may be private, State or mixed and which usually also comprise companies or entities established in other countries. ${ }^{66}$ Furthermore, the NCP considers that the OECD Guidelines expressly establish principles and standards for responsible business conduct, which is generally understood as the responsibility of entities involved in business or commercial activities. Whether an entity can be considered to have commercial activities, is to be determined by the competent NCP on a case-by-case analysis based on the concrete circumstances. ${ }^{67}$ To understand the situation of FIFA, the NCP's next step was to ascertain the legal construction of FIFA. FIFA is not a single legal entity, but exists of several entities which are enlisted in the Commercial Register of the Canton of Zurich. Additionally, FIFA owns a number of foreign subsidiaries. Secondly, the NCP analysed what sort of activities FIFA undertakes, which it derives from the bidding contract between FIFA and its direct counterparties in Qatar. The bidding contract is very comprehensive and includes various topics of commercial nature, e.g. media marketing rights, finance and insurance, etc. The conclusion of the Swiss NCP is therefore, that since FIFA consists of different entities active in more than one country, it has a multinational scope and since the activities of FIFA include activities of commercial nature, the OECD Guidelines are applicable. ${ }^{68}$

Regarding the materiality of the specific instance, the NCP considerd that while BWI has referenced various violations of migrant workers' rights in Qatar, the role of individual actors according to the different provisions of the OECD Guidelines needs to be further explored. ${ }^{69}$

\footnotetext{
66 Ibid. P. 6.

67 Ibid.

68 Ibid.

69 Ibid. P. 7.
} 
Therefore the NCP offered its good offices for further mediation between BWI and FIFA in order to reach a mutually acceptable outcome. Parties accepted this offer and after six meetings in 2016 mediated by Prof. Christine Kaufman ${ }^{70}$ a mutual agreement was reached which is included in the NCP's Final Statement issued on 2 May 2017. In this agreement BWI and FIFA identified five areas they considered of particular relevance: 1) identification and use of FIFA's leverage on relevant actors in Qatar; 2) the Human Rights Policy emanating from Article 3 of the 2016 FIFA Statutes; 3) a robust process for monitoring labour conditions; 4) mechanisms for workers' complaints and grievances; and 5) establishment of an oversight/advisory body.

Regarding the first point FIFA accepts its responsibility to mitigate risks by aiming to build and exercise its leverage whenever possible with all relevant actors in Qatar in order to ensure decent and safe working conditions for the 2022 World Cup. ${ }^{71}$ Additionally, they agree that in the context of the bidding requirements for future editions of the World Cup the approach should be based on strengthening the due diligence process. ${ }^{72}$ Thereto FIFA will follow guidance from the OECD Guidelines and the UN Guiding Principles on Business and Human Rights. Furthermore, BWI and FIFA agree that it is essential to secure human rights compliance of subcontractors throughout the supply chain, which complexity increases for tiers three and four. With respect to a robust process of monitoring labour conditions, parties, including labour inspections at FIFA World Cup related project sites which will be worked out in a separate Memorandum of Understanding between BWI and FIFA. ${ }^{73}$ Parties also agreed that a BWI representative will become a member of FIFA's Human Rights Advisory Board which will take up its work in 2017 and will issue recommendations to FIFA twice a year. ${ }^{74}$ Both parties will also engage with Qatar to improve the effectiveness of grievance mechanisms for workers. ${ }^{75}$ Lastly, BWI and FIFA agreed

${ }^{70}$ Professor on Human Rights at the University of Zurich.

${ }^{71}$ NCP Switzerland, Final Statement, 2 May 2017. P. 3.

${ }_{72}$ Ibid.

73 Ibid. P. 4.

${ }_{74}$ Ibid. P. 5 .

75 Ibid. 
to meet regularly, at least twice a year, to update each other about the human rights situation in Qatar and to exchange ideas of cooperation to contribute to ensuring decent work and safety in the workplace for migrant workers until the completion of the 2022 World Cup in Qatar. ${ }^{76}$

\section{CONCLUDING REFLECTIONS - SEIZING THE MOMENT FOR CHANGE THROUGH SOFT LAW}

The first thing I want to reflect on is the role of trade unions in the transnational setting. Two of the three cases discussed in this contribution were raised by trade unions. The case at the Swiss court was initiated by the Dutch trade union FNV, the Bangladeshi Free Trade Union Congress, and the Bangladesh Building and Wood Workers Federation and the specific instance with the Swiss NCP was submitted by the global union federation BWI. The significance of this lies with the fact that while migrant workers in Qatar were (and still are) not allowed to organise themselves, they do find themselves represented by trade unions. More importantly, in both cases the trade unions were accepted as parties having an interest, even though they didn't represent the migrant workers directly. Especially the specific instance with the Swiss NCP indicates the added value of global union federations to interact with organisations at transnational level. All though global union federations still face many challenges, ${ }^{77}$ they do fill a representative gap which is in any case better than having no representative body at all. In particular in this situation both, the ITUC and BWI, have proven their added value.

The second point I want to reflect on is the added value of quasijudicial procedures. The Swiss Court was very quick to dismiss the case. One of the reasons was that it considered that the first claim of Plaintiffs, i.e. to order FIFA to redress the ongoing human rights violations by pressing the responsible Qatari authorities to abolish the

${ }^{76}$ Ibid.

77 Cf.: Müller T., Platzer H.-W., and Rüb S. Global Union Federations and the Challenges of Globalisation. International Policy Analysis (2010); and more generally Fairbrother P., Hennebert M.-A. and Lévesque Ch. (eds.). Transnational Trade Unionism. Building Union Power, Routledge (2013). 
controversial Kafala system, could potentially be deemed unlawful. As such the Swiss Court completely ignores the nowadays generally accepted expectation of transnational organisations to identify, prevent and mitigate actual and potential adverse impacts and account for how these impacts are addressed. ${ }^{78}$ This is even expected where the MNE itself has not contributed to the adverse impact, but when the impact is nevertheless directly linked to the operations, products or services by a business relationship. ${ }^{79}$ This is an expectation of business, including an organisation like FIFA, and requires certain actions of the multinational enterprise. With whom the MNE needs to engage exactly within the country it is doing business is never defined. Moreover, this is open and depends on the situation and the risks involved and what is needed to prevent or mitigate the adverse impact. In the situation of FIFA it is clear that with the award of the 2022 World Cup to Qatar more migrant workers are being subjected to a vulnerable situation of modern slavery created by the Kafala system. Therefore it is expected of FIFA to engage with whatever organisation - private or public - to prevent or mitigate the adverse impact of awarding the 2022 World Cup to Qatar.

For the Swiss Court this situation was apparently too vague to issue a ruling on. This is clearly different with the other two procedures. Of course the Article 26 Complaint differs from the outset in that it is directly aimed at Qatar and the fact that Qatar is blamed for allegedly failing to comply with its obligations under the ILO Conventions. However, this Complaint and the Specific Instance with the Swiss NCP have in common that they are based on a process of engagement. In the Article 26 Complaint the ILO engaged with Qatar to identify and work towards solutions to stop the infringements. The Swiss NCP offered its good office to mediate between FIFA and BWI in order to reach a mutually acceptable agreement. Both procedures involved several meetings and exchanges of information as well as trust and commitment between the two parties involved to reach an outcome for future and ongoing change of conduct towards (more) compliant behaviour. Thus, instead of a retrospective, single instance decision regarding a clear and fixed rule (which is typical for a court ruling), these softer mechanisms

${ }_{78}$ Par. 10 General Principles of the OECD Guidelines for MNEs.

79 Par. 12 General Principles of the OECD Guidelines for MNEs. 
accept compliance as a complex process that requires an organisation or State to undertake meaningful activities that creatively, critically, and continually, redress their performance and improve it.

Both soft law processes have resulted in an ongoing engagement with Qatar and FIFA in order to create change. In these procedures many changes have already been announced, some have already been effected, some not yet and are merely promises for the moment. Some issues have only been addressed and new laws and policies still need to be developed. Nonetheless, a process has started that seems irreversible. More particularly, Qatar has undertaken the first steps to abolish the Kafala system and FIFA has adopted a Human Rights policy, including a Human Rights Advisory Board, which applies also to its subsidiaries and subcontractors.

A lot has happened since in 2010 FIFA awarded the 2022 World Cup to Qatar. Regrettably, this includes an outrageous number of fatalities among migrant workers. Nonetheless, some positive things have also come from it which give hope for a better future of the migrant workers in Qatar and for all (migrant) workers involved with the organisation and construction of buildings and infrastructure for future FIFA World Cups.

\section{REFERENCES}

Bahrain Moves to Reform Kafala, Exclusions Remain. Americans for Democracy. Oct. 28. 2016.

Conn, D. (2017). Thousands of Qatar World Cup workers "subjected to life-threatening heath". The Guardian. Sept. 17.

Erfani, A. (2015). Kicking Away Responsibility: FIFA's Role in Response to Migrant Worker Abuses in Qatar's 2022 World Cup. Jeffrey S. Moorad Sports Law Journal. 22 (2). 623.

Fairbrother, P., Hennebert, M.-A., and Lévesque, C. (eds.) (2013). Transnational Trade Unionism. Building Union Power. London: Routledge.

Gereffi, G., Humphrey, J., and Sturgeon, T. (2005). The governance of global value chains. Review of International Political Economy. 12:1. 78 . 
Grell, T. (2017). FIFA's Responsibility for Human Rights Abuses in Qatar. Part I: The Claims against FIFA. Asser International Sports Law Blog. Feb. 28.

Grell, T. (2017). FIFA's Responsibility for Human Rights Abuses in Qatar. Part II: The Zurich Court's Ruling. Asser International Sports Law Blog. March 6.

Harmassi, M. (2009). Bahrain to end "slavery" system. BBC Arabic Service Radio. May 6.

ITUC. Qatar Arrests 100 Striking Workers for Deportation. Nov. 26, 2014.

ITUC. The case against Qatar. Host of the FIFA 2022 World Cup. Special Report. March 2014.

Laughland, O. (2017). FIFA official took bribes to back Qatar's 2022 World Cup bid, court hears. The Guardian. Nov. 15.

Liew, J. (2017). World Cup 2022: Qatar's workers are not workers, they are slaves, and they are building mausoleums, not stadiums. The Independent. Oct. 3 .

Müller, T., Platzer, H.-W., and Rüb, S. (2010). Global Union Federations and the Challenges of Globalisation. International Policy Analysis.

ter Haar, B. Ph. and Keune, M. (2014). One step forward or more window-dressing? A legal analysis of the recent CSR initiatives in the garment industry in Bangladesh. The International Journal of Comparative Labour Law \& Industrial Relations. 30:1. 5.

The Middle East's migrant workers. Forget about rights. The Economist. August 10. 2013.

Toumi, H. (2011). Calls to implement summer working hours in Qatar. Gulf News. May 15. 